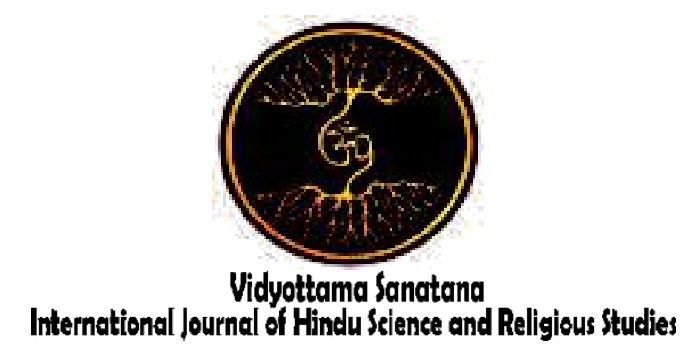

Vol. 3 No. 1 May 2019

\title{
OGOH-OGOH ATTRACTION OF NYEPI RITUAL IN BALI
}

\author{
By: \\ I Wayan Suharta \\ Institut Seni Indonesia Denpasar \\ E-mail : wynsuharta@gmail.com
}

\begin{tabular}{|l|l|l}
\hline Received: Pebruary 5, 2019 & Accepted: May 6, 2019 & Published: May 31, 2019
\end{tabular}

\begin{abstract}
Ogoh-ogoh as an artwork and at the same time is a cultural phenomenon in the social life of the Balinese community besides being filled with symbolic values, also giving freedom of expression. Not only does it elevate mythological tales, but it also raises actual everyday themes that are used as autocritical expressions of social phenomena. Ogoh-ogoh in performance art is a spectacle of a combination of works of art, art, and mechanical technology. It is a creative effort of young artists to innovate. Ogoh-ogoh is seen as a central figure, even appointed as the theme of the artwork. The dancers play certain characters according to the characterization in the story, the results are displayed in the form of dance fragment. Animatronic adopted and combined with performance art is a form of the latest developments in performing arts in Bali. It becomes a challenge, because the technology continues to grow. Aesthetic sensitivity is needed, namely the synergy between dance, music, fine art, and mechanical technology, involving skilled and qualified personnel in their respective fields.
\end{abstract}

Keywords: Nyepi, Ogoh-ogoh, Creativity, Innovation.

\section{Introduction}

Nyepi day that falls every year is indeed very unique. In fact, many say it is more unique than other religious celebrations in Bali. For this reason, the celebration of Nyepi is considered an important moment, not only for Balinese Hindus but also other
non-Hindu communities. Apart from being unique, which is clearly indicated by the absence of daily activities, a quiet road, no one selling, not traveling and so on, but philosophically has universal values that are relevant to the current global context. 
Nyepi with Catur Brata Penyepian which is amati geni (no fire), amati karya (no working), amati lelungan (no traveling), and amati lelanguan (no fun/pleasure), is the true essence of Nyepi, a general philosophy people should be understood worldwide. This philosophy is not only true for people who are Hindu in Bali, but also for everyone, if it is infused and interpreted more deeply (Suryawan, 2019: 6).

Therefore it becomes interesting to follow empirical facts on Nyepi in 2019 quoting Suartana's statement (2019: 6). From various sources, during the celebration of Nyepi Day in Bali there was a reduction in carbon dioxide emissions of approximately 20,000 tons in a day, electricity savings of around 70 percent if it was equivalent to around $\mathrm{Rp} 4.5$ billion, water savings and other fuel savings. Bali is a day without pollution (even close to zero percent) as a source of climate change and weather anomalies.

One thing that must not be overlooked, that every community group before Nyepi is always creative in creating works that resemble Bhuta Kala, Wayang, and other characters in the form of Ogohogoh to be carried on the night of Pengrupukan. The ogoh-ogoh procession and attractions a day before Nyepi have been tradition, so Nyepi without Ogoh-ogoh feels less flat. Even when calling Ogoh-ogoh, then we will remember Nyepi and the afternoon attractions carrying Ogoh-ogoh around the village accompanied by Balaganjur gamelan.

The Ogoh-ogoh attraction with the Tawur Kasanga ceremony is a creative expression of Hindi people in Bali in the turn of the Year of Caka. First echoed in the 1980s. Initially it appeared in Denpasar and continued to expand to all corners of Bali, even to the outside of Bali. In its development, young people who joined the SekaaTerunaTeruni in every banjar, continued to develop their creations. Then the Ogoh-ogoh created can take the form of Bhuta Kala, such as: Kala Bang, Kala Ijo, Kala Dengen, Kala Lampah, Kala Ireng, and there are also imitating the artists who become their idols (Widana, 2012: 6).

Whatever the form of Ogoh-ogoh, of course what is expected by the community, especially the younger generation, can interpret the existence of the Ogoh-ogoh. Moreover, it has something to do with religious ceremonies, namely as an effort to restore the characteristics of 'bhuta kala' to its origin, which in the end is expected not to disturb the lives of the people in order to live in harmony and peace.

This article will present a critical study of Ogoh-ogoh as anartwork and at the same time is a cultural phenomenon in the social life of Balinese society, which is full of symbolic values and an inspiration in the creation of performing arts. The review focused on Ogoh-ogoh as an innovative performing art which is a blend of works of performing arts, fine art, and mechanical technology.

\section{Result and Discussion \\ 1. The Creative Process of Making Ogoh- ogoh}

Ogoh-ogoh as a form of creativity, often associated with Tawur Kasanga a series of Nyepi. Ogoh-ogoh which was paraded when Pengrupukan was generally in the form of Bhuta Kala paraded after the execution of tawur with the logic that when they wished for nyomya bhuta kala, they needed to be invited first. After being invited and given an offer, then they returned to its original place so as not to interfere with human life. 

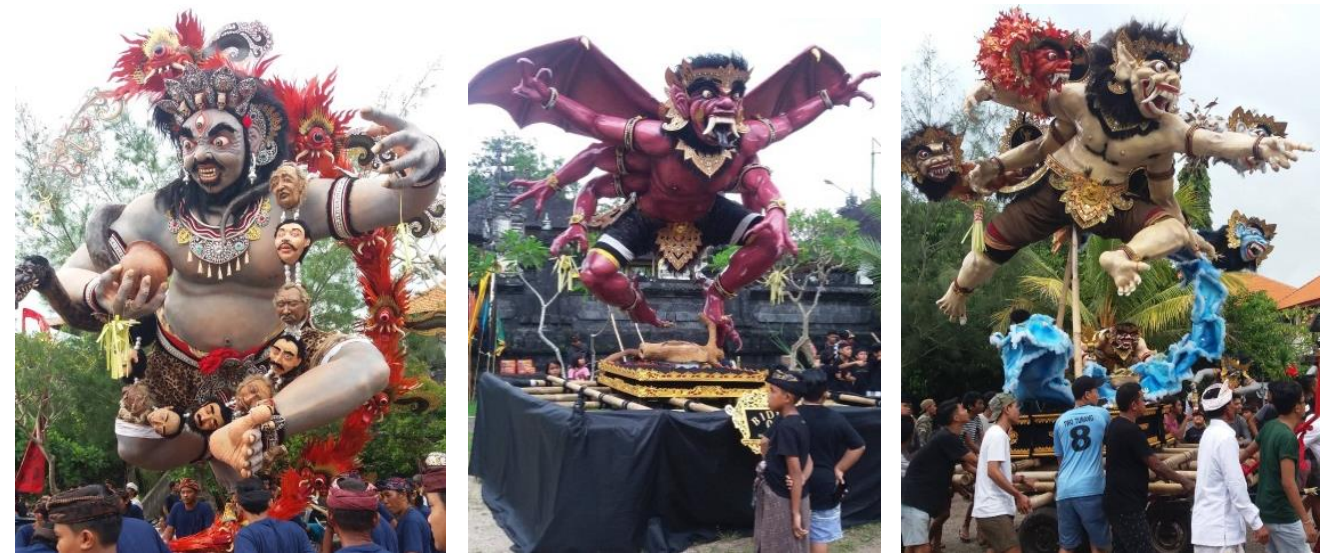

Ogoh-ogoh the participants of the Ogoh-ogoh Parade Competition

in the Village of Pecatu 2019

Ogoh-ogoh is a pile of three-dimensional shapes, which are made of assembled solid, soft or flexible materials which are then wrapped in layers of paper or cloth, colored and plastered with hairs resembling human, animal, or a combination of humans and animals in the form of charactersmythological characters such as butha kala, gods and puppet figures. In the past Ogohogoh making materials used bamboo and wood as staples with minimal coloring. Nowadays the materials used are very varied, ranging from bamboo, iron frame wood, sponges, to modern painting techniques. In line with the development of flexible design technology and many rotational techniques used, although it is still semi-manual.

There are two prominent themes related to the activities of making Ogoh-ogoh (Astita, 2005: 6). First, it is an expression of the religious thinking of the Balinese people in respect of space and time that is manifested through the natural cycles and daily cycles of human life. Human routines begin when people are aware of their various needs, so that they are required to move until the time they experience nothingness. This cycle revolves in the reality of time which is mostly not sacred, nor is it time that is sacred. There is no ogoh-ogoh that is sacred even though in the making it has undergone an initiation process. Ogoh-ogoh is only a secular manifestation of the abstraction of sacred symbols about time space that are very free in shape.
The second theme is related to the creative process which results from the existence of space and time. This creative process finds its momentum in the yearly celebration of the Çaka year as a yearly cycle that is celebrated by Hindus in Bali as Nyepi Day. After successfully realized, the Ogoh-ogoh are then enjoyed, observed and admired by various interpretations in accordance with the subjectivity of the audience. If the Ogoh-ogoh has been formed, the ritual process is carried out. At least the pemelaspas ceremony was held to show their sincerity to live something meaningless to be meaningful for life.

Ogoh-ogoh as anartwork and at the same time is a cultural phenomenon in the social life of Balinese society besides full of symbolic values, it also gives freedom of expression, not only raises mythological tales but also raises actual everyday themes and even used as an autocratic expression of social phenomena.

\section{Ogoh-ogoh Grows the Spirit of Togetherness}

The development of Ogoh-ogoh every year is constantly changing. Both of the materials used, the work, the implementation process, and so on. One interesting thing in making Ogoh-ogoh today is a practical impression. In 2012, unwittingly making Ogoh-ogoh has undergone a creative cultural shift that has been held by Balinese people for generations, namely the art culture of 
grapevine. If previously it was necessary to make Ogoh-ogoh need patience, especially in the bamboo field, so that it became the manifestation of Ogoh-ogoh. Now, with a large cork, Ogoh-ogoh artists work more practically.

Simply by slicing the cork sticking in accordance with the desired embodiment, Ogoh-ogoh can easily be made, and from a number of activities making Ogoh-ogoh, many use ingredients from cork. Even though the price of one cork is fifty in hundreds of thousands of rupiah, the yield is far better than using the previous conventional method of weaving bamboo.

Making Ogoh-ogoh likened to making a large statue with a large size. To make one Ogoh-ogoh measuring 3 meters high requires substantial funds. This group of Ogoh-ogoh makers in seeking funds must request donations to a number of residents and entrepreneurs in their respective regions. The funds needed for Ogoh-ogoh are not just to solve Ogoh-ogoh, but it is necessary to think of costumes for the carrying ones. Of course this is to show the compactness of the bearer group, at least the same costume is needed to show their identity.

The creativity of the young generation in the cultivation of Ogoh-ogoh grew well and was so lively. Later Ogohogoh is made more modern, so the process is done in a long time and requires a fee. Creative young people need to eat and drink. Usually the ones who work on Ogoh-ogoh are only a few people, but other members certainly are also there with other tasks. If one day there are 20 people struggling there, then the cost of their food and drink must be borne. Moreover, a little extra drinking is rather expensive to increase the enthusiasm for work, so the total cost of Ogoh-ogoh is very high.

However, the spirit of the young generation makes Ogoh-ogoh worthy of appreciation. Bearing in mind there is a kind of 'prestige' in each banjar to show artistic ability and cohesiveness. Therefore, the issue of funds often does not count in detail, most importantly can be obtained through fundraising. Usually it can be done by holding a bazaar, asking for donations from the house to the house, donations from companies around the banjar, and others.

Important things that need attention, do not let the younger generation in making Ogoh-ogoh productivity decline. Can be creative, but do not get late in the banjar hall to make Ogoh-ogoh, by ignoring the main work. In essence, how Ogoh-ogoh is made once a year, is able to foster a sense of brotherhood, mutual cooperation, understanding togetherness and spiritual level for the better. Certainly it is not expected because Ogoh-ogoh actually caused a stir and tension between members of the community.

\section{Ogoh-ogoh in the Performing Arts}

Ogoh-ogoh attractions in recent Nyepi celebrations have experienced significant developments, presented as a result of the creativity of artists who combine works of art with performance art. Ogoh-ogoh is seen as a central figure, even appointed as the theme of the artwork, while the dancers portray certain characters according to the characterization in the story. The results of this creativity are displayed in the form of dance fragment.

The emergence of the "Ogoh-ogoh fragment dance" is as a representation and aesthetic expression of the artists, developed or received inspiration from the art form that already existed before. Development that is rooted in traditional arts has adapted to the conception of art or taken some of its elements. In Bali, artists are very fond of performances with a spectacle mission whose contents vary. This gives an opportunity for artists to develop their creativity. Artists can freely display dramatic characters from certain performances to bring different roles. The concept of creativity in the fragment of the Ogoh-ogoh dance was identified from classical art to modern art. 


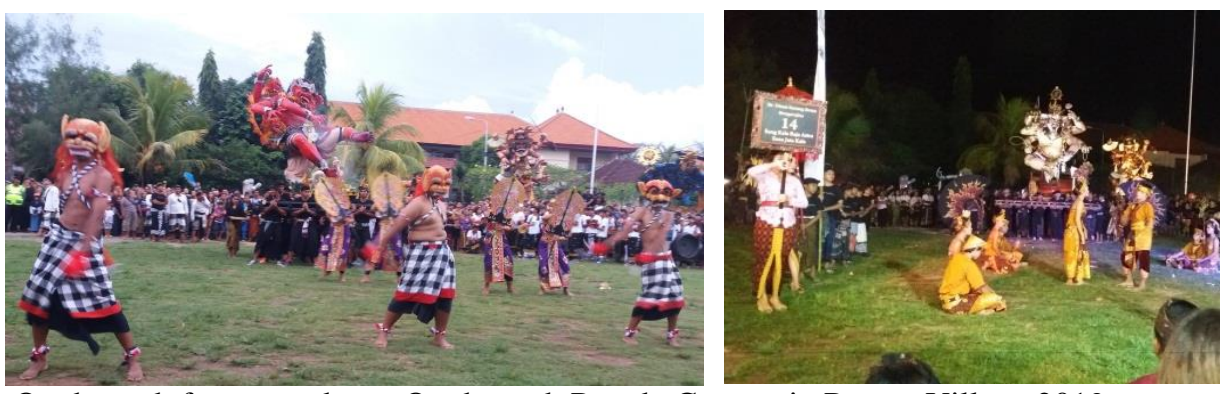

Ogoh-ogoh fragment dance Ogoh-ogoh Parade Contest in Pecatu Village 2019

As Munandar revealed (in Murgiyanto, 2004: 68), creativity can be done based on traditional materials or new materials. Understanding of the traditional values and the nature contained in this Ogoh-ogoh is the provision of an artist in processing it into a form of performance art that is in harmony with the spirit of tradition and the level of development of life. Without deep understanding of traditional values, creativity only produces works that are even good, but will feel strange. Without the creation of creativity, the face of art will not be in harmony with the development of today's life.

In line with his opinion Edi Sedyawati (1983: 3), that creativity is not only entrenched in modern works, because contemporary art is a product that responds to new phenomena. Thus new works, new style variations, new themes can always be created by artists within the limits of the rules that can be felt by supporters of tradition in general.

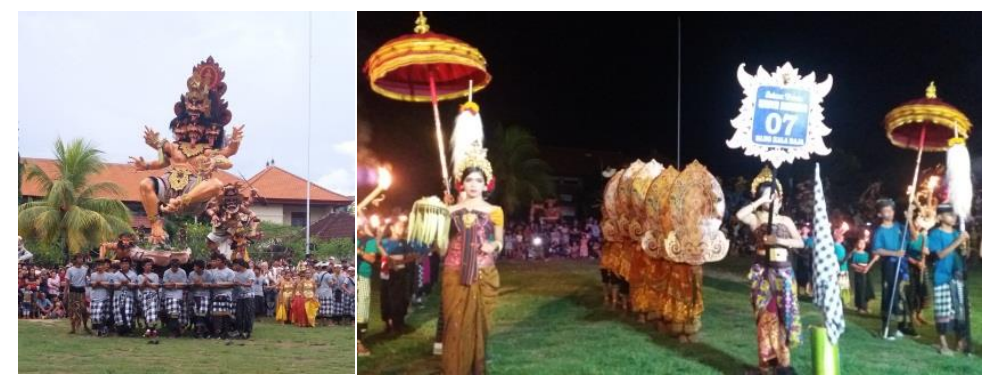

Ogoh-ogoh attractions begin with a row of signboards and canangrebong

Conceptually, the Ogoh-ogoh dance program was also built from a combination of several elements of classical art and new creations, showing a combination of elements of art, dance, and music. The concept of this art is a representation of a crystallization of aesthetic desires in the context of the existence and development of various performing arts in Bali. Citing the opinion of The Liang Gie in Suartaya (2001: 123), every human art work is an artistic reconstruction to be enjoyed by its beauty values. Enjoyment is indeed only to get pleasure, excitement, satisfaction and relief in human emotional life without many other factors that can interfere.

In modern times like today, when human life is more oriented to material culture than spiritual ones, art tends to be seen as a mere source of entertainment rather than as a vehicle for inner enlightenment. Those who come to an art show in general with the aim of entertaining themselves. In many respects according to Dibia (2003: 93), art functions more as a recreational medium to release all the burden of the mind including mental tension after a hard day's work. Indeed, if we pay close attention, in Balinese art, both art and performance, there is an aesthetic content inspired by noble cultural values.

\section{Balaganjur as Music Accompaniment}

The media used to accompany the Ogoh-ogoh fragment is a Balaganjur gamelan set, which is a gamelan that has its 
own nuances, character and identity. To support developing ideas, stylists try to visualize with various variations and existing techniques, oriented to logic, ethics and aesthetics in Balinese gamelan.

The making of the Ogoh-ogoh fragment dance art form using Balaganjur's accompaniment was a challenge for the stylists, because of the characteristics of Balaganjur which limited the creativity of a composer. Balaganjur has strong and dynamic characteristics, which are only suitable to accompany the themes of heroism, struggle, and various other themes that are violent and dynamic. Therefore, the creation of an accompaniment of the Ogohogoh dance fragment, will depend on the ability of the stylist in processing the elements of music according to the theme being worked on.

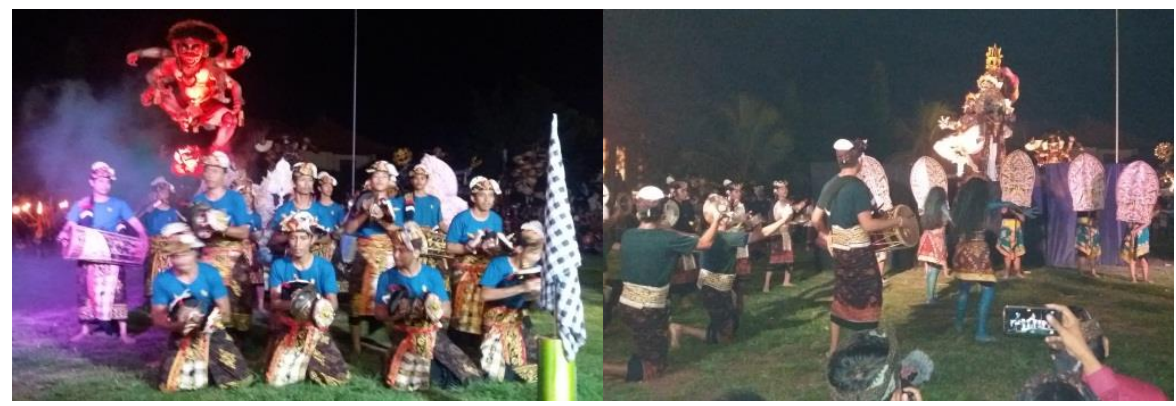

Baleganjur musician accompanied the Ogoh-ogoh dance fragment

As an accompaniment of the Ogoh-ogoh dance fragment, the creation of musical works is more focused on developing new game techniques and melodic nuances. In implementing the concept of balance and harmony, it is realized through the prominence of the balance element in its musical aspects. Process musical elements in Balaganjur with artistic tips to create the expected atmosphere.

The musical accompaniment of the Ogoh-ogoh dance fragment is a new creation of musical works, namely 'audio visual karawitan' as a manifestation of 'instrumental karawitan' which is also combined with 'vocal karawitan'. By utilizing Balaganjur gamelan media, the stylists developed a model for creating Balinese music which has now been influenced by creativity 'the creation of music' due to the touch of a culture of plural Indonesian society.

Such is the development of Balaganjur to this day, that Balaganjur is not merely a presentation of instrumental music, but also functions as a complete accompaniment of performing arts. In the context of adat and Hinduism in Bali, Balaganjur is a musical accompaniment, but in its development, Balaganjur besides being present with its identity as an instrumental ritual music, Balaganjur later spread into performing arts that were very worth watching, functioned to accompany Ogohogoh attractions, and now it has developed into a dance fragment.

The enthusiasm of Balaganjur's creation among the people in Bali is certainly very positive, how Balaganjur can play a flexible role in harmony with the circumstances and demands. According to Suartaya (2005: 8), the universe approach to art through Balaganjur is one of the natural alternatives in the Balinese context to save young shoots as human resources for the future of the nation.

\section{Innovation in Ogoh-ogoh}

The current of globalization which inevitably plagues Bali, demands the need for rapid and appropriate changes in all lines of Balinese life that are known to be synonymous with customs, culture and tradition. Bali as a living entity full of cultural aura requires conservation efforts as a manifestation of Balinese manners. Global flows that are not in line with Balinese 
customs and culture must be addressed wisely (Kresna, 2019: 6).

Tradition no longer has to be opposed to change or innovation. That tradition developed and changed. Change, because it can never satisfy all of its supporters. However, tradition does not change by itself, but gives an opportunity to be changed and requires someone to make changes. The continuity of a tradition depends on the continuous refresher or innovation of its supporters (Murgiyanto, 2004: 2).

Demands for change must be seen and addressed with clarity of heart accompanied by wise thoughts and wise implementation. The new challenges created through Ogoh-ogoh must be able to adjust the demands of the existing changes, while maintaining the Balinese cultural identity. Ogoh-ogoh is a Balinese culture sub-culture that is synonymous with the involvement of young people. It is because the making of ogoh-ogoh is almost 90 percent carried out by young people in each banjar or group. This young Balinese artist sincerely expresses his imagination and creation into the ogoh-ogoh he made. This is in accordance with the homo-imaginarius concept; humans as creatures that have the ability to do imagination (Artanegara, 2019: $6)$.

The social interaction of the community during the process of making Ogoh-ogoh has become increasingly tight, which is due to the symbolization of BhutaKala this seems to be a separate icon for the banjar and group. Although the parents were not directly involved in making Ogoh-ogoh, they still hoped for the best from the results of this young artist. There is tremendous pride if they are able to be creative according to their own beautiful taste (Suci, Sonhadji, Imron, \& Arifin, 2018).

The development of Ogoh-ogoh was able to step over the standard by using styrofoam materials by reason of the process of making fast and expressive forms that wanted to be displayed more dynamically. However, after the struggle of Ogoh-ogoh artists and support from the local government, the use of Styrofoam is prohibited because it can cause damage to the environment.

Apart from this, the use of technology has been thought of by young artists in Bali. Ogoh-ogoh, which was originally static, began to be developed innovatively, which was able to move on its part of the frame, even though it was still driven by 'mechanical manual'. But in the last two years, the use of microcontrollers that function as electronic circuit controllers and can store programs in them, has been implemented on Ogoh-ogoh collaborated with google assistant technology or with sensors, began to be developed (Artanegara, 2019: 6).

Collaboration between dolls and robotics technology like that, actually has developed a long time called 'animatronics'. According to the Wikipedia Free Encyclopedia, animatronics is the use of robots to imitate humans or animals or to make an inanimate object such as having the nature of living things. The results of animatronics are called animatronics. Not much has been glimpsed in Bali, because this animatronic is a combination of art and mechanical technology. It becomes an opportunity for young artists to apply animatronics in making Ogoh-ogoh in Bali. 

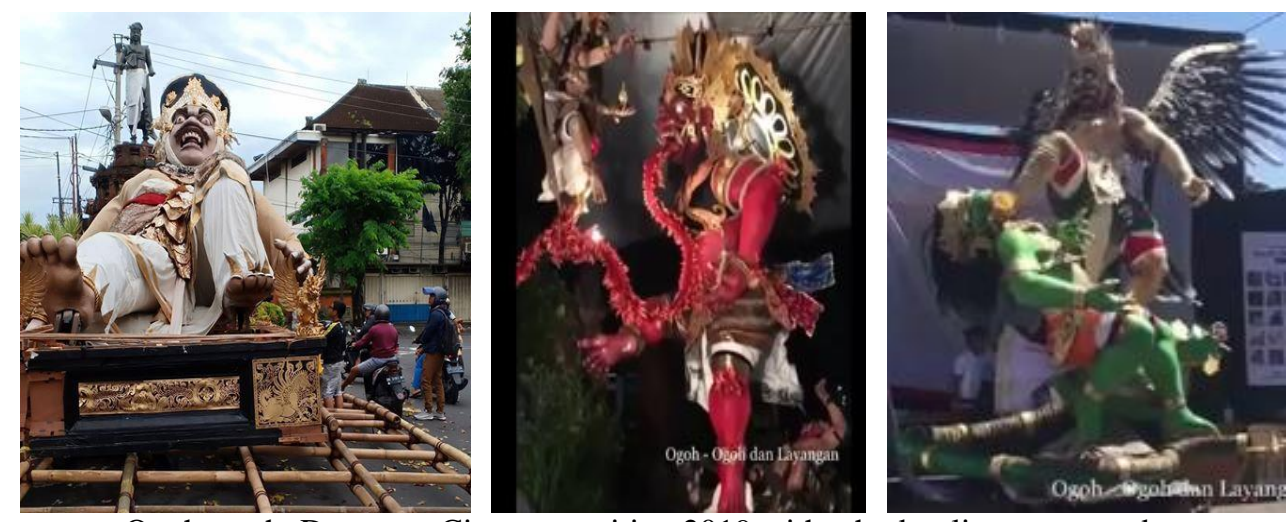

Ogoh-ogoh, Denpasar City competition 2019 with a hydraulic system and an android system

The latest developments in the use of animatronics in making Ogoh-ogoh in Bali, ranging from manual, android, and hydraulic systems. Manual system; on-of using button switch, android system; driving control using a phone. Whereas the hydraulic system; spring system (the driving system from the sleeping position becomes standing). Hydraulic work systems are the same as the 'crank motor' work system in general, in each joint in the Ogoh-ogoh (such as ankles, knees, waist) driven using a hydraulic thrust.

\section{Ogoh-ogoh as an Innovative Performing Art}

Some aspects that determine and become a requirement, that Ogoh-ogoh as an innovative performing art which is a combination of works of art, art, and mechanical technology, are: aesthetic concepts, creative attitudes, artistic tips, and continuity in change.

\section{a. Aesthetic Concepts}

The aesthetic concept refers to a principle that concerns something that can give a sense of pleasure, in contrast to other feelings of excitement related to usability. So an aesthetic conception is how the design in the process of creation is compiled to make a work of art that becomes beautiful. Conceptually the creation of Ogoh-ogoh as an innovative performing art rests on the basis of aesthetic concepts, namely the norms of beauty in Balinese performing arts.

In general what is called beautiful, in the soul can cause pleasure, satisfaction, security, comfort and happiness. If the feeling is very strong, feels transfixed, moved, and fascinated and creates a desire to enjoy that feeling even though it has been enjoyed many times (Djelantik, 2004: 4).

\section{b. Creative attitude}

The creative attitude of an artist arises because of the instinctive urge to work as a burst of emotional outburst, while the urge to progress is an ethos of art that encourages to produce quality work. As a creative artist is very motivated by various situations and motivation to produce new works. In idealism, according to Koentjaraningrat (1987: 258), the attitude in developing new discoveries or creating new works is the awareness of the individual's lack of culture and the stimulating system of the activities of creators in society.

Along with this, one in the paradigm of change theory is stated, that society always wants to adjust to changes caused by internal influences and external influences. Referring to this theory, people always want a new nuance, not satisfied with what is already there (Kartodirjo, 1993: 163). Young Artists in Bali, of course, do not want to let the traditional arts become frozen, slumped, and even sink into the era. Therefore, each generation continues to strive to make innovations. Artists are aware, creative and selective to give fresh ideas in order to give a new breath that can bring art closer to the context of the lives of its people.

\section{c. Artistic Tips}

Tips are tactics or strategies as a careful plan for activities to achieve specific goals (Balai Pustaka, 2002: 438). The artistic 
strategy in the context of the intended creation is a strategy used to compile a new work so as to produce quality work. Artistic techniques or art techniques are closely related to the contents of their ideas. So the original idea will guide a stylist to give birth to new techniques and forms (Sudirga, 2003: 86). Ogoh-ogoh as an innovative performing art, requires harmony between aspects of ideas, aspects of form, and aspects of presentation. The contents intended are ideas or central themes about what is to be conveyed. Is it just an atmosphere, message or message as a creative power and imagination. While the structure is how to express a central idea, Ogoh-ogoh, which is the media, he said.

\section{d. Continuity in Change}

Ogoh-ogoh as an innovative performing art which is a blend of works of performing arts, fine art and mechanical technology, still shows Balinese cultural identity, is insoluble and drifts into the establishment of the past. Able to offer renewal concepts as the development of traditional art forms as an implementation of the spirit and spirit of progressive Balinese people. According to Bandem (1991: 8), saying that change without awareness of equipping oneself with basic characters will be at very high risk, disorientation, loss of direction, and eventually will be able to produce works with a giddy identity and character.

Many artists have created works as an expression of more free creativity. In this context, conceptually it seems that the stylist offers new nuances and breath that are more individual, even the rules of tradition do not have to be taboo but something that must be developed. In reality, even though there is more free space in the nuances of the present, freedom still pays attention to normative ethics in the frame of the traditional format by applying the concept of sustainability in its changes.

\section{Conclusion}

Ogoh-ogoh in performing arts is a form of the latest developments, a spectacle of a combination of works of art, art, and mechanical technology. It is a creative effort of young artists to innovate. The artists consciously and selectively incorporate ideas into the traditional arts that they inherited from ancient times, with the aim of giving a new 'breath' that can bring the art closer to the people of their time. In general, Ogohogoh is an attraction, and Ogoh-ogoh's creativity continues. Among the creativity done, there are certain accentuations that use technology. By utilizing technology, it has actually made innovations or changes. The changes that occur are the result of the creativity of artists who offer or refresh their audience.

When animatronic is adopted and applied in the performing arts, it is certainly a challenge because the technology continues to grow, it requires skilled and qualified personnel in their respective fields. For young artists, it becomes a promising opportunity to continue working and creativity, because Ogoh-ogoh attractions as a series of Nyepi routines take place every year. Aesthetic sensitivity is needed, namely the synergy between dance, music, fine arts, and mechanical technology.

Performing Arts in Bali, actually still save a lot of uniqueness that can provide stimulation as a land to work to give birth to various new forms of work. Therefore, with no intention of patronizing, as an art lover, people should realize that the land of creativity will never run out as long as there is still the desire to search for and explore the 'gold mine' which is still buried in the art world in Bali. Creativity to produce works of art is not static, but always moves dynamically along with the times and the human mindset. It should be used as a reflection especially for the younger generation who are engaged in the world of performing arts, that makes the creative moment of Nyepi celebration the theme of work is very important to be traditionalized in the academic environment and also in the community environment. 


\section{References}

Artanegara, I Gusti Agung Gede. 2019. Ogoogoh, Bhuta Kala, Inovasi dan Animatronika. Bali Post, Rabu Kliwon, 6 Maret 2019, halaman 6.

Astita, I Nyoman. 2005. Mitos di Balik Ogoh-Ogoh. Bali Post, 26 Maret, Halaman 6.

Bandem, I Made. 1986. Prakempa : Sebuah Lontar Gamelan Bali. Denpasar : Akademi Seni Tari Indonesia Denpasar.

Bandem, I Made. 1991. "Peranan Kesenian Dalam Menunjang Pembangunan Daerah Bali". Sekolah Tinggi Seni Indonesia Denpasar.

Dibia, I Wayan. 1999. Selayang Pandang Seni Pertunjukan Bali. Bandung : Masyarakat Seni Pertunjukan Indonesia.

Dibia, I Wayan. 2003. "Nilai-nilai Estetika Hindu dalam Kesenian Bali", dalam Estetika Hindudan Pembangunan Bali. Denpasar : Program Magister Ilmu Agama dan Kebudayaan Universitas Hindu Indonesia Bekerjasama dengan Penerbit Widya Dharma.

Djelantik, A.A. Made. 2004. Estetika Sebuah Pengantar. Bandung : Masyarakat Seni Pertunjukan Indonesia.

Hadi, Y. Sumandiyo. 2000. Seni dalam Ritual Agama. Yogyakarta : Yayasan Untuk Indonesia.

Kartodirdjo, Sartono. 1993. Pendekatan Ilmu Sosial Dalam Metodologi Sejarah. Jakarta : PT. Gramedia Pustaka Utama.

Koentjaraningrat. 1987. Sejarah Teori Antropologi I. Jakarta : Universitas Indonesia Press.

Kresna, Agung. 2019. Kejernihan Hati Menata Desa Adat. Bali Post Rabu Umanis, 27 Maret 2019, Halaman 6.

Mack, Dieter. 2001. Musik Kontemporer dan Persoalan Interkultural. Bandung : Jalasutra.

Murgiyanto, Sal. 2004. Tradisi dan Inovasi Beberapa Masalah Tari di Indonesia. Jakarta : Wedatama Widya Sastra.
Puspawati, L. P., Ariana, I. K. E., \& Suastika, I. M. (2018). An Ecological Aspect Of The Text Kuttara Knda Dewa Purāna Bangsul Concerning Mount Batukaru. Vidyottama Sanatana: International Journal of Hindu Science and Religious Studies, 2(1), 163-174.

Rai S, I Wayan. 1998. "Unsur Musikal dan Ekstra Musikal dalam Penciptaan Gending Iringan Tari Bali”. Dalam Mudra Jurnal seni Budaya, No. 8 Th. VIII Sekolah Tinggi Seni Indonesia Denpasar : UPT Penerbitan.

Sedyawati, Edi dan Sapardi Djoko Damono (editor). 1983. Seni Dalam Masyarakat Indonesia. Jakarta : PT. Gramedia.

Soedarsono, R.M. 1998. Seni Pertunjukan Indonesia di Era Globalisasi. Dirjen Dikti Departemen P dan K Jakarta.

Suartana, I Wayan. 2019. Spirit Nyepi dan Keuangan Berkelanjutan. Bali Post Senin Pon, 4 Maret 2019. Halaman 6.

Suartaya, Kadek. 2001. "Transformasi Cak Dari Ritual Magis Ke Presentasi Estetis". (Tesis). Program Pasca Sarjana Universitas Udayana.

Suartaya, Kadek. 2005. Dilombakan, Balaganjurpun Manjur dan Menjamur. Bali Post, 11 September, halaman 8.

Suci, I. G. S., Sonhadji, A., Imron, A., \& Arifin, I. (2018). Organizational Harmony in Hindu Higher Educatiob Institution based on Tri Hita Karana Culture. Vidyottama Sanatana: International Journal of Hindu Science and Religious Studies, 2(1), 49-59.

Sudirga, I Komang. 2003. "Kajian Komposisi Karawitan Karya I Nyoman Windha”. Dibiayai oleh Program (Due Like) Batch IV STSI Denpasar Tahun Anggaran 2003, Sesuai dengan Persetujuan P2MPT Tanggal 21 Juli 2003 : Program Studi Seni Karawitan Sekolah Tinggi Seni Indonesia Denpasar. 
Suryawan, I Gst. Ngr. Bagus. 2019. Nyepi, Yadnya Agung bagi Kala-kala. Bali Post Senin Pon, 4 Maret 2019, halaman 6.
Tim Penyusun Pemda Tingkat I Bali. 1992. Catur Yadnya (Bhuta, Manusa, Pitra, Dewa). Denpasar : PT Upada Sastra.

Widana, I Gusti Ketut. 2012. Nyepi: "From Eufo To Zero". Bali Post : Kamis Kliwon, 22 Maret 2012 